\title{
Love and the stranger: Intimate relationships between Aboriginal and non-Aboriginal people in a very remote Aboriginal town, northern Australia
}

\author{
Cameo Dalley \\ The Australian National University
}

\begin{abstract}
Intimate relationships between Aboriginal and non-Aboriginal people have generally been pursued within the transactional modalities afforded by economy and kinship (e.g. Hamilton 1972; Tonkinson 1990; Redmond 2005). A parallel anthropological literature (e.g. Myers 1979; Venkatesan et al. 2011), however, has critiqued these emphases, and has instead highlighted the need to consider the emotional experiences of individuals. One of the types of individuals considered here is the stranger, a figurative character that Simmel (1950: 403) described as 'no owner of soil'. In this paper I explore the experiences of one of these strangers, 'Andrew', a non-Aboriginal man who was the partner of an Aboriginal woman and living in the remote Aboriginal town of Mornington Island in the southern Gulf of Carpentaria. In interpreting Andrew's experiences, I argue for an analytic frame based on understanding how transformative personal encounters including love can bring together and sustain relationships between those of (sometimes) vastly different socio-cultural backgrounds.
\end{abstract}

Keywords: Aboriginal Australia, emotions, stranger, love, intimacy, non-Aboriginal

\section{INTRODUCTION}

In the context of social relations within Australia, marriages and de facto relationships between Aboriginal and non-Aboriginal people pose interesting questions as well as challenges about the degree to which Aboriginal people might be socially and physically incorporated into broader Australia. Much anthropological theorising has been done on the conceptualisation of Aboriginal people as 'intercultural', transitioning in some senses towards identities which are more in common with other Australians (see Dalley and Martin this volume). As many have now explained for the contemporary period and with extrapolations into the past, Aboriginal life cannot be conceived of as independent or sealed locales of activity, meaning-making or subsistence. Rather, Aboriginal lives are thoroughly intercultural. The appearance of a reduction in difference, however, obfuscates real and enduring barriers in the articulation of Aboriginal social identities and the ways in which both Aboriginal and non-Aboriginal people 
actively participate in boundary-riding on the fringes of identity, thereby emphasising cultural boundedness and authenticity (Trigger 1997: 98-9; Merlan 2005: 181; Tonkinson and Tonkinson 2010: 69; Cowlishaw 2012: 398).

With an acknowledgement of Aboriginal sociality as thoroughly intercultural come questions about the propensity or desire to incorporate those who do not selfidentify as Aboriginal, but for various reasons seek inclusion or are sought to be included in Aboriginal people's lives. Here I mean to include both those working with and for Aboriginal people and those whose attachments are more intimate; as friends, lovers and partners. These individuals represent a vital component in the understanding of relations, part of an approach that Cowlishaw (2010: 54) called for and where 'the lifeworlds of all residents are elements of one set of social relations, dealt with on equivalent terms'. In remote locales where the local population of a continuous and emplaced Aboriginal majority have relatively few direct interactions with those originating from outside their known social world, these questions have particular salience. This paper is focused on one such case study drawn from Mornington Island, a very remote Aboriginal town in northern Australia where approximately 100 non-Aboriginal people co-reside with 900 Aboriginal people.

Such is the role of the outsider, sometimes designated as 'the stranger', in places like Mornington Island that they can take on figurative meaning and are used as an allegory to characterise cultural systems. They are therefore a key to unlocking both what it means to belong within a group and to exist outside it and to understanding at what point the boundaries between these two supposedly bounded states might collapse. In contexts further afield, such as Papua New Guinea and South America, Gell (1996: 3) and others (e.g. Strathern 1992; Vilaça 2002; Herriman 2012; Viveiros de Castro 2012) have deployed the stranger in this analytical fashion (see also McGrath this volume). That is, the stranger becomes a heuristic device used to contemplate the permeability of a society, both to receive someone from elsewhere and to (potentially) 'make them kin'. As the German sociologist Georg Simmel ([trans. Wolff] 1950: 402) wrote of the stranger:

He is fixed within a particular spatial group, or within a group whose boundaries are similar to spatial boundaries. But his position in the group is determined, essentially by the fact that he has not belonged to it from the beginning, that he imports qualities into it, which do not and cannot stem from the group itself.

In the context of the relations between Aboriginal and non-Aboriginal people explored in this paper, one of Simmel's important observations was of the stranger's ability to make claims of/to a shared 'substance'. Though often focused on substances which are embodied, especially blood and skin colour, other substances such as cash (Austin-Broos 2003), and meat (see Redmond this volume), have also proven theoretically potent schema in anthropological analysis (Carsten 2011; R. Martin this volume). Partly this is because their flows and consubstantiation create opportunities for the social reproduction of sharing and relatedness or alternatively, differentiation and autonomy, which are fundamental to Australian Aboriginal social life. The substance 
identified by Simmel as most relevant to understandings of the stranger was that of 'soil'. As Simmel (1950: 403) described:

the stranger is no 'owner of soil' - soil not only in the physical, but also in the figurative sense of a life substance ... although in more intimate relations, he might develop all kinds of charm and significance, as long as he is considered a stranger in the eyes of the other, he is not an 'owner of soil'.

Settling down and becoming recognised as an 'owner of soil' meant that the stranger had largely overcome their inherent potential to wander. In Australia, the pastoral industry and the colonial frontier have provided ethnographically rich examples of these phenomena and of the interactions between non-Aboriginal and Aboriginal people that they entail. Some have suggested that such relations exemplify the way in which Aboriginal people might incorporate others, 'relative strangers', into their social worlds, rendering them into 'strange relatives' (Redmond 2005).

\section{SHARED SUBSTANCE AND THE INCORPORATION OF STRANGERS}

The historical incorporation of strangers or non-kin by Aboriginal people in Australia, especially as partners, lovers, husbands and wives on the colonial frontier, is a much explored phenomenon in fiction and popular culture (e.g. Prichard 1929; Herbert $1938,1975)$. Some of these narratives also included children of mixed-descent, the products of these sexual unions between Aboriginal and non-Aboriginal people. Such was governmental concern about miscegenation, most frequently between Aboriginal women and non-Aboriginal men, that it was made illegal in some states of Australia during the late nineteenth century, a history described by Ann McGrath (1987, 2005) for the Northern Territory and Queensland.

Extrapolating the impact of this history into the present, Hannah Robert (2001: 69) has pointed out how such relations now make uneasy subject matter in that they 'play out the metaphors of conquest, penetration and violation' by White men against Aboriginal women. Similarly, as Victoria Burbank (1995: 191) noted, 'whether sexual congress between white men and Aboriginal women was affected by force or by choice, the legacy of this interaction in Australia is not a benign one'. Thus, interracial relationships occupy a fraught conceptual space, colliding physical and ideological bodies which are both highly racialised and sexualised. While fictional accounts have dealt with this difficulty by exploring themes such as love, longing and desire, the few existing anthropological explorations of interracial relationships between Aboriginal and non-Aboriginal people in Australia have most frequently been pursued within the transactional modalities afforded by economy and kinship. That is, attention has been paid to the ways in which Aboriginal people extend 'the kinship web indefinitely outwards' (Redmond 2005: 234) to incorporate others and in order to elicit the kinds of reciprocity for which Aboriginal people are renowned.

Annette Hamilton (1972: 42), for example, described an historical economisation of relations between 'blacks and whites' where Aboriginal people 'give the white man 
an Aboriginal woman'. In Hamilton's (1972: 42) estimation, this 'giving' serviced a desire to be able make 'claims on the whites', albeit via forms of indenture which were not immediately recognised on the part of the latter. This rendering of Aboriginal women's bodies in terms not inconsistent with Marcel Mauss' (1954 [1950]) famous explication of 'the gift', in which the giving is partly or entirely geared toward inducing particular kinds of reciprocity from the pastoralists, suggests a commoditisation of sexual relations by both pastoralists and Aboriginal people. In a comparable example from the Western Desert, Robert Tonkinson (1990) described similar entanglements but contemplated the complicities of Aboriginal women in this process, opening up the possibility that 'women alone took such decisions' (1990: 128-9). Regardless of the agency of the parties, in both Hamilton and Tonkinson's historical observations, the coming together of Aboriginal women with non-Aboriginal men was framed as an economic and therefore logical accommodation to the harshness of colonial frontier (McGrath 2005). These relations also sat alongside emerging reductions in the potency of traditional Aboriginal marriage laws and expectations, developments which were facilitating a more mobile social reality for Aboriginal women via the expansion of marriage choices beyond the gerontocracy of older Aboriginal men.

Anthony Redmond (2005) has described how, in the Kimberley region of Western Australia, Ngarinyin Aboriginal people historically incorporated non-Ngarinyin, particularly pastoralists, through processes of exchange whereby 'relative strangers' were rendered 'strange relatives' (2005: 234). While the extension of the existing and prevailing kinship idiom to incorporate 'others' was not without its own internal complexities and compromises, it instantiated what was already a generalised ethic among Ngarinyin people, that is, to cultivate and proliferate relations which were both socially and economically interdependent. An important factor in the Kimberley was that these kinds of elicitation emerged as particular responses to the dominance of the pastoral industry and, usually, White pastoralists involved in it (see also Davis 2004 and a variety of accounts by Kimberley Aboriginal people in Shaw 1992). Similar observations have been made of the pastoral industry elsewhere in Australia, such as those by Benjamin Smith $(2003,2006)$ for Cape York and Richard J. Martin (this volume) for the mainland Gulf of Carpentaria.

Across these various contexts, working on stations provided a source of income for Aboriginal people while also mediating their access to land, impacting on their resource procurement and the maintenance of social and ritual responsibilities (Smith 2003: 90; Redmond 2005: 236). For pastoralists, Aboriginal people provided cheap and readily available labour while at the same time having detailed and invaluable knowledge of the country that the pastoralists were working. Hence, land was the key link between Aboriginal and non-Aboriginal people, at least in the first instance, and the economic benefit derived from its continual occupation provided the logic for why a pastoralist, a 'stranger', might decide to remain. Analyses of 'mutual dependencies' between Aboriginal and non-Aboriginal pastoralists have highlighted how, over time, processes became 'entrenched', supported by, and interwoven with, intermarriages (Redmond 2005: 238). Some mixed-descent children even went on to become 
station managers and owners, the multi-generational quality of their connections and interconnections compounding their intensity and complexity.

It is possible to conclude, then, that over time some pastoralists became recognised by some Aboriginal people both as 'owners of soil' and as having a 'shared substance', to use Simmel's phrasings, in common with Aboriginal people. But is it sufficient to see such relationships as solely the product of interdependency crafted through economic relations within a kinship idiom? While these kinds of incorporation often include intimate relationships, the interpretive frame remains one in which reciprocity is continually checked and to a degree fetishised, as though on a ledger between social actors (Povinelli 2006: 49; Berlant 2011: 687). For Jankowiak and Fischer (1992: 149), such emphases 'bind the individual emotionally into a web of dependency with others, thereby rechannelling or defusing the intensity of an individual's emotional experience'. Yet it is these emotional experiences, richly elaborated in particularised sociocultural contexts, which are fundamental to notions of personhood and self.

In Fred Myers' (1979) exegesis on the understudied field of emotion and the self in Aboriginal contexts, he argued that the many volumes of ethnography had 'for the most part concentrated on Aboriginal kinship systems and has said little about the way in which the Aboriginal world is structured from the point of view of the individual' (1979: 343). Or to put it another way, that the dialogically constructed aspects of self so fundamental to kinship, had taken a disproportionate pre-eminence over those experienced individually. Myers attributed this to the muting of readily identifiable emotions (perhaps with the notable exception of anger) in the daily lives of Pintupi Aboriginal people. One of the emotions of concern to Myers that has received comparatively little attention subsequently has been the construction of romantic relationships between Aboriginal people (cf. Burbank 1995). Partly this is because, as Myers (1979: 344) concluded, reading or characterising feelings such as love or intimacy is not as easy as it first appears' and partly because, as Jeanette Edwards (in Venkatesan et al. 2011: 213) more recently put it, 'what constitutes love and how it is lived is rare in the ethnographic account'. Though Myers' analysis was primarily of Pintupi Aboriginal people, it also extended to non-Pintupi (dubbed 'Europeans' in Myers' account) with whom they co-resided. This paper further builds on this analysis, asking: are there modes of analysis which are more attentive to the emotive and intersubjective character of interracial relationships between Aboriginal and non-Aboriginal people? And, how might these relations play out in contexts where land does not or cannot act as a mediator?

\section{WHITEFELLAS AND CONTINGENCY ON MORNINGTON ISLAND}

The interpretation of interracial relationships as transformative and personalised experiences of love is set within my broader studies of social relations between Aboriginal people and Whitefellas in a very remote town in northern Australia (Dalley 2012). The former Presbyterian Church mission settlement of Gununa on Mornington Island had a resident population of approximately 1000 people in 2011 (ABS 2011: Table 
B07), where a local Aboriginal majority (90\%) lived alongside a smaller non-Aboriginal population. ${ }^{1}$ Working in the local school, hospital, police service, council and other administrative bureaucracies, 'Whitefellas' as they were referred to locally, constituted a 'present absence' in the social life of the island, seldom crafting long-term interpersonal relationships with local Aboriginal people. ${ }^{2}$ A range of locally-specific phenomena helped construct this situation, including the spatial layout of the town which concentrated accommodation for Whitefellas in particular areas that were themselves often delimited by physical barriers. Such was the security associated with one of these areas in which local health service employees resided that at least some Aboriginal people referred to it as 'Guantanamo Bay'. ${ }^{3}$ The deviance associated with this spatial separation, where identity was inscribed in the residential distribution of people across the landscape, physically sealed most Whitefellas off from Aboriginal people in their domestic lives. These separate living arrangements fed into and mirrored the generalised lack of intimate knowledge that Whitefellas had of local Aboriginal lives and vice versa.

Though the minutiae of their daily lives are far more complex and varied than can be discussed here, suffice it to say that 'Whitefellas' were not socially or culturally homogenous. Indeed, data collected during the annual Census in both 2006 and 2011 showed a range of ancestries including Chinese, Indian, Irish, Maori, New Zealander, South African and Scottish (ABS 2006: Table B08; ABS 2011: Table B08). ${ }^{4}$ Based on the Census data it is much more difficult to ascertain class-based distinctions which may also play a key role in the formation of relations between Aboriginal and nonAboriginal people. However, interviews undertaken with locally resident Whitefellas around this same period disclosed important heterogeneities in education, age, income, and gender, factors which contributed to particular Whitefellas socialising with some individuals and not others. These factors, which coalesced into social cleavages, were perhaps most noticeable with a smaller sub-set of approximately seventeen men who were the husbands (via registered marriage) or de facto partners of local Aboriginal women. ${ }^{5}$ Interpreting how these 'different kind of Whitefellas' defined their own identities and how their relationships with other residents were defined by others provided insights into local relations in much the same way as has been reported for the stranger elsewhere (e.g. Gell 1996: 3).

The men had varying life trajectories which had brought them to the island: as teachers, tradesmen, prawn trawler fishermen or, less commonly, those working in local administrative bureaucracies. Their length of residence on the island varied from a year to many decades, and at least one had reportedly 'gone through Law', undertaking the ritualised accumulation of ceremonial knowledge which is accompanied by circumcision. The veracity of stories about these Whitefellas was difficult to establish and they were also the subject matter of outlandish tales, including that of one man who was supposed to have fallen off a prawn trawler as a child and who had subsequently been raised by an Aboriginal family, and another who was said to be a bank robber on the run from his native Ireland. However implausible, these narratives served as status logic for why these men had ended up in the town and as justifications 
for their disavowal of their own cultural backgrounds. This logic extended into explanations for why these men chose to reside, as they usually did, with their Aboriginal partners in housing which was designated for the use of Aboriginal people by the local council.

Despite this spatial positioning in the town, it seemed that houses where these men were resident were not visited or frequented by Aboriginal people to the same extent as houses where only Aboriginal people lived. Whether or not this autonomy extended to being able to deny or thwart demands from Aboriginal kin for cash and resources was less obvious, but certainly having a non-Aboriginal partner may have increased the avenues for doing so. In various instances this included some Aboriginal people referring to them by using local Aboriginal kin terms reckoned through their Aboriginal partner. Whether the relationships inferred by the kin terms were considered by others as genuine, a 'polite fiction' or entirely bogus depended on the social settings in which they were being deployed, and the status of the Aboriginal person who was using them (McKnight 1999: 33).

This contingency meant that these men were seen by others (and sometimes themselves), as occupying an interstitial social and geographical space, neither incorporated into the Aboriginal social world nor with other Whitefellas. For example, one of these Whitefellas aged in his fifties described to me how he was a 'stranger', and an 'outsider' among local Aboriginal people, even though he had lived on the island for over 10 years and had fathered a child with a local Aboriginal woman (Field notes 30/9/ 2006). This strangeness or outsider status was sometimes reaffirmed by these men's behaviour, which seemingly resisted attempts for them to be cast otherwise, a point often noted by Aboriginal people. In one instance an Aboriginal man commented to me on the inexplicability of one of these men's (his brother-in-law's) behaviour: 'you think 'e'd know, 'e live on this island long enough'. Another example was that of an older 'Frenchman' Jehovah's Witness who had lived in the town for over 40 years, often rode a pushbike around the town and periodically doorknocked to distribute the Watchtower magazine. These instances of what Aboriginal people (and others) saw as idiosyncratic behaviour, or as a disregard for what was considered locally appropriate, seemed to confirm the men's classification as 'misfits', which is a view shared by at least some anthropologists to have worked in the region. David McKnight (2002, 2004, 2005) who undertook field research on Mornington Island from the 1960s, contextualised the ongoing association of the men with Aboriginal people as reflecting their inability to 'cope with the outside world', suggesting that they 'find it irksome and dull living with White Australians' (2002: 221).

This 'misfit' classification fitted into the vernacular categorisation of 'mercenary, missionary and misfit', a triad often used to describe non-Aboriginal people living and working in remote locales (Townley 2001; Kowal 2011: 9). What appeared particularly evident, though, was the degree to which this rendering was generated by other resident Whitefellas, especially those who had less extensive periods of residency and had moved to the island to work in the myriad of service delivery roles. One such woman who lived on the island with her husband during the mid-2000s, for example, 
commented about the men that 'you just go "holy smokes!"', and 'you know that they can't fit into mainstream society' (Interview transcript 16/6/2009). What struck me, however, were the affective connections that the men had made with their Aboriginal partners and by extension, local Aboriginal families, and the seemingly transformative nature of these experiences on their senses of self. These connections had undoubtedly irrevocably changed their life trajectories. At the same time, this intimacy afforded them (perhaps more than other strangers living on the island), insightful reflections on the meanings of difference in that localised context. The remainder of this paper focuses in detail on the experiences of one of these Whitefellas.

\section{TRANSFORMATIVE EXPERIENCE AND THE FORMATION OF A NEW RELATION}

'Andrew' (as I will refer to him), moved to Mornington Island in the early 2000s after successfully applying for a position as a community health worker advertised in a regional newspaper. Andrew had grown up in the city of Cairns and had spent much of his life a self-described 'drifter', working and moving intermittently around north Queensland. Shortly after arriving on the island he began a relationship with a local Aboriginal woman who he had gotten to know through his work and within a short space of time the woman had fallen pregnant with the couple's first child. This development would come to mean a great deal both in the context of their relationship and of Andrew's position in the local social world. The couple had a number of other children subsequently. Self-identifying as Catholic and having 'grown up' as a Catholic, Andrew had 'always wanted a family' but explained that in his past, 'whenever someone I was with got pregnant, the pregnancy wasn't continued'. This contrasted to his Aboriginal partner who 'for all her faults, was the one that when she fell pregnant there was no inkling that she wouldn't have it [the baby]'. Subsequently Andrew went on to master the role of 'nurturing domestic' in the household, showing all the hallmarks of an intensely devoted father, who was frequently seen around the town with his children and who regularly commented on his enjoyment of their company. Coming to fatherhood somewhat later in life, like Andrew, or having a second family with an Aboriginal partner, like other Whitefellas on Mornington Island, was not uncommon among non-Aboriginal men partnering with Aboriginal women. Part of the reason for this was because of the age differences that often existed between Aboriginal women (often still of child bearing age) and their older non-Aboriginal partners.

By fulfilling his lifelong desire to be a father, Andrew's partner had returned him to a particular aspect of his own youth which continued to resonate (having 'grown up Catholic') while at the same time transforming his sense of self from that of a 'drifter' to a reliable (and therefore worthwhile) parent. The intersection between becoming something new (a father) and returning to what he had always been (a Catholic) was fundamental to his attachment to his partner and he was 'very glad that she was that kind of person'. The dual carriage of these two aspects of selfhood, what Kronqvist (2012) referred to as the 'lost and found' of intersubjectivity, had enabled Andrew 
to conceive of himself as complete, loving and whole, and to find a centre of identity, perhaps unexpectedly for him, rooted in a nurturing domesticity. It was at least partly his commitment to domestic life that Andrew attributed to changes in his relationship with co-resident Aboriginal people, especially his partner's family. In showing himself to be a committed partner and father, a person whose sense of belonging was inextricably crafted in concert with that of his Aboriginal kin, Andrew reversed stereotypes. As he described it, this contradicted the more common reality that within the life of the town, Aboriginal people 'were used to men disappearing and not being responsible for their children'.

This tendency was noted by previous anthropologists who have worked in the region and also the psychoanalyst Virginia Huffer (1980), who spent short periods interviewing Aboriginal women on Mornington Island in 1970 and 1973. Huffer (1980: 155) also commented that the prevailing ethic at that time was for continuity and reaffirmation of Aboriginality. Such was this desire that a number of statements from older Aboriginal women set out 'that they hoped that their daughters would marry dark-skinned men, not white men', the latter being a practice that was becoming more prevalent at that time. Huffer (1980: 140) estimated during the 1970s that $10 \%$ of children on Mornington Island had White fathers but that begetting mixeddescent children did not attract the same degree of criticism as ongoing co-habitation between an Aboriginal woman and a Whitefella. One explanation for this that has been noted elsewhere for this region (Trigger 1989: 219), is the relative ease with which mixed-descent (Aboriginal/Whitefella) children were incorporated socially as being within the category 'Aboriginal'.

On Mornington Island the maintenance of Aboriginality continued to have currency in the 2000s, though there was a perception among some Aboriginal women that Whitemen were, in fact, 'more better' than potential Aboriginal partners in that they would 'look after you'. This 'looking after' was a product of supposedly greater financial security, the perception that they were less prone to commit domestic violence and that they were more likely to be monogamous and 'not dogs', a reference to the perceived sexually promiscuous nature of canines (see also Musharbash 2010: 280). The naturalisation of mixed-descent children as being within the category 'Aboriginal' seems to have extended a kind of generosity to their Whitefella fathers. Andrew explained that:

they [Aboriginal people] allow me to stay here and I don't cop any violence, no one tries to get at me. And no one tries to intimidate my kids or anything. And my [Aboriginal] families stick up for me because they care about me.

Andrew's children granted him, by extension, something undeniably in common with his Aboriginal 'families': a 'life-substance', to use Simmel's (1950: 403) term, which made clear his relation in more than affinal terms. This life-substance firmly positioned Andrew on the grid of the local Aboriginal genealogy and brought him a kind of recognition among his Aboriginal families, not necessarily one founded in intimacy, but of structured relatedness. While the authority of genealogy has been 
critiqued by some (e.g. Povinelli 2002: 216), including most fervently by Haraway (1997: 265), for Andrew and perhaps for other strangers like him, this level of inclusiveness was foundational to other developments in his life in the community.

Being the parent of mixed-descent children altered Andrew's status with the local council as it related to housing. There were no houses available for private rent on the island and the tenancy of the limited housing that was available was dedicated to Aboriginal people under an agreement with the Queensland State Government. ${ }^{6}$ In special circumstances the tenancy board, comprised mostly of local Aboriginal people, had discretionary powers to grant housing leases to others who could justify a claim for residency, mostly non-Aboriginal men who were the primary carers of their mixed-descent children. In Andrew's situation he 'made a case to the people that made those decisions to be able to control the environment, who comes and who goes, for the welfare of my children'. This request, to be granted inclusion as an exception, highlighted Andrew's position as an 'outsider' and of his children as both key interlocutors between him and the local Aboriginal community, and as a means of engendering social inclusion and genealogical relatedness. As well as the housing situation, the local council (comprised solely of Aboriginal councillors) also had the power to eject people from the Shire under the Local Government Act 1993 (Qld). Although these powers were seldom enacted, there were at least two reported examples where nonAboriginal men were supposedly 'asked to leave' or 'moved on' following the death of their partner or the breakdown of their relationship. ${ }^{7}$

This system, where Aboriginal people had prioritised access to housing and residency, made the ongoing presence of Whitefellas in the town highly contingent. Compounding this was that local Aboriginal people had previously had their rights in land and sea recognised under the Native Title Act 1993 (Cth) through successive claims in 2004 and 2008. ${ }^{8}$ This particularity was not lost on Andrew. In his words, 'they do it their way, this is their land, they've got sea rights and land rights and in a person's mind that gives them the idea that they can do it all their own way'. The recognition afforded to Aboriginal people as the rightful owners of the local geography enforced the alterity of men like Andrew and their perpetual codification as Simmel's (1950: 403) stranger who is 'no owner of soil'. Unable to purchase land or even to take up a private rental agreement, Andrew's residence on the island was dependant on him being able to access the same services (especially housing) as local Aboriginal people. This situation made him the target of ridicule among some Whitefellas, notably those who had come to Mornington Island to work in service delivery. For example, Andrew recounted a situation where another local Whitefella had reportedly noted, 'what a situation you're in, the locals hate you for being a Whiteman living with a Black woman and other White people hate you for living off the system'. In this case the 'stranger' (Andrew), through his very presence in the town, was seen to be making illegitimate claims against services which were established to improve the living conditions of Aboriginal people. The supposed 'hate' that other Whitefellas had for him reflected a cynicism for any non-Aboriginal people who might be 'living off the system'. ' When asked how he reflected on this rendering, Andrew was circumspect: 
at times, stress can reduce people's perception of you to a racial stereotype. I know that happens. Race relations are a big problem here and there's good reasons but that stuff is used as a smoke-screen for some.

While it was generally the case that Mornington Island Aboriginal people had a sense in which all resident Aboriginal people and non-Aboriginal people who had 'married in' were all 'one family', perceived threats to individuated identity or access to resources, such as housing or jobs, precipitated retreats to entrenched racial positions. During instances of instability non-Aboriginal people otherwise glossed as part of the Aboriginal 'family' were sometimes referred to as a 'White cunts' or, less commonly, as a 'ngumbuldaan' (a Lardil word translated literally as a person who has sexual intercourse with their mother, that is the proverbial 'mother-fucker'). In these instances, the precariousness and contingent nature of their relatedness held in common with Aboriginal people became more readily apparent, their positioning being reduced to the supposed boundaries of their racial category. In any case the resentment Aboriginal people and other non-Aboriginal people might have periodically felt and displayed towards Andrew was for him outweighed by his enduring commitment to his partner and children, connections which grounded him physically to Mornington Island.

In his time across the Wellesley Islands, Andrew had also developed a strong relationship to the local environment, describing his 'love' for the 'wildness of the place', remembering it as a 'feeling' that had 'came up through the soles of my feet' the first moment that he had arrived on the island. Recalling Benjamin Smith's (2006) account of a Cape York Aboriginal man's framing of his connection to country as 'more than love', Andrew's stated connectivity invokes something of the autochthonous centring in and from place which has so defined Australian Aboriginal people's spiritual and ritual links to country. Statements such as Andrew's were not uncommon among non-Aboriginal residents who used the (involuntary) possession of the schema of their own bodies to account for feelings of fixedness in place. At the end of my first day on Mornington Island in 2006, for example, I referred to the place as 'already getting into my blood' (Fieldnotes 20/9/2006). These visceral manifestations of connection can be accounted for by the potent experience of arriving and then becoming resident in a place which is so remote and so different to most Australian towns and cities. Further, the sentiments accord with what Peter Read (2000: 5) described as the 'starting-point' for the recognition that 'emotions and intuitions are part of deep belonging'. Read's (2000) work in the area of non-Indigenous belonging in Australia embraces the embodiment of connection, and here emphasises the lack of choice that the Whitefellas felt they had exercised in its establishment, it being an almost other-worldly possession. ${ }^{10}$

The corporeal embodiment of connectedness to place felt by some of the nonAboriginal residents of Mornington Island, however, was of a single generation. This differentiates them from the compounding genealogical connections of pastoral families elsewhere in northern Australia as described by Redmond (2005) and Richard J 
Martin (this volume). Hence, Andrew's belonging to Mornington Island was again of a different tenor to that of local Aboriginal persons who had had their rights to land and sea recognised through native title determinations in 2004 and 2008. The combination of these factors meant that in casting his gaze forward, Andrew saw a 'very uncertain life with an uncertain future', one which he did not see as sustainable. When asked to contextualise this statement he mused: 'in the long-run I don't believe that they will allow me to live peacefully here', perhaps hinting at the potential enactment of powers to eject people from the Shire under the Local Government Act 1993 (Qld).

Andrew's biographical narrative and statements about the future contrast to McKnight's (2002: 93) characterisation of such Whitefellas on Mornington Island as having 'drifted into the community ... linked up with local girls' while showing 'little concern for the future'. Rather, Andrew was acutely aware of the uncertainty of his future: 'I want to know what happens to this place. I want to see how that ends up. I want to know what goes on here, not that I have any right to or even any real reason to I guess'. Andrew's feeling that he 'cannot stay forever' accords with Simmel's (1950: 402) conceptualisation of the stranger as a 'potential wanderer' in that 'although he has not moved on, he has not quite overcome the freedom of coming and going', in the same way that his placement on the Aboriginal genealogy was contingent. Although for the time being Andrew was fixed 'within a particular spatial group' which defined him as a resident of Mornington Island and a father whose children had an autochthonous connection there through their mother, his attachment was not inattentive or naive to the racialised nature of his own position.

\section{DISCUSSION}

The growing number of relationships between Aboriginal and non-Aboriginal people and of anthropological characterisations of Aboriginal people as 'intercultural' may falsely suggest seamless integrations of non-Aboriginal people into Aboriginal social schema. There are few who have undertaken fieldwork which pays attention to the experiences of non-Aboriginal people who are co-resident with Aborigines (Cowlishaw 2003: 11; Lea 2012: 188). On Mornington Island it may be the case that as McKnight (2005: 142) observed: 'Aboriginal women often took the leading role in establishing a relationship with a European Australian', and as he put it, 'that they did so (and do so) for a variety of complex economic and social reasons'. It is these kinds of reasons, especially those offered by the structured economic and kinship economies, which have formed the basis of previous anthropological explanations of such relations in Australia. However, the overly deterministic nature of these interpretations has come at the expense of understanding the emotions of the individual (Jankowiak and Fischer 1992: 149).

Yet locating love and intimacy in interracial relationships is a difficult and incomplete task. On the one hand is the desire to recognise universal human emotions, while on the other is the need to account for the diversity of ways in which these emotions are experienced and expressed (Burbank 2014: 2). For the Pintupi that Myers studied, 
such emotions were expressed using terms of reference highly mediated by local expectation, a point later reinforced by Yasmine Musharbash (2008) in another Central Australian ethnography. Musharbash (2008: 145) commented that the 'obliqueness' of quotidian intimacy among Warlpiri people meant that it was only accessible to those who were astute readers of the most subtle of bodily movements (i.e. Warlpiri themselves) (see also Glaskin 2012). As Myers explained for the Pintupi (1979: 347), 'I found it very difficult to elicit private or individual's interpretations of experience', as distinct from what he saw as the cultural expectation of emotive reaction (1979: 349). This was certainly the case on Mornington Island where, although there were instances where Aboriginal Mornington Islanders described love for children, it was less common to witness overt displays of affection between partners, such as kissing, holding hands or hugging.

The intention here is not to characterise Aboriginal people as emotionally austere, but to highlight the enciphered nature of such emotion, such that it is difficult to interpret by outsiders. Nevertheless, in most matters the anthropological purview is seemingly adept at reading through, rather than taking at face value, the relationships which sustain and make intimate forms of social life. Entering into this complexity is the figure of the stranger, here taken to be a non-Aboriginal man in a relationship with an Aboriginal woman. Andrew's life and his coming into a new kind of being through his relationship with his partner showed evidence for a transformation of his sense of self. In his own contextualisation of the relationship Andrew had exposed what Berlant (2011: 684) described as the 'revolutionary kernel'; a kind of attachment which might explain the 'impulse to throw it all over through the leap of coordinating oneself with virtual strangers, and then to become a part stranger to oneself in the emerging atmosphere of the new relation'. For Andrew the key to this 'new relation' was his love for his children who, through their classification as 'Aboriginal', acted as mediators between their father and local Aboriginal social forms.

A sentimental analysis might see their relationship as an example of what Povinelli (1995: 45) described as a kind of modern love which 'exfoliates the social skin, what produces racial difference as if it were simply a skin that can be peeled away, leaving behind the true self. Yet even Andrew was not naive to the reality that the kind of ideological exfoliation referred to by Povinelli was utopian, and that 'at times, stress can reduce people's perception of you to a racial stereotype'. In the Mornington Island example, these relations were embedded in local authority structures where the power of the local council to evict non-Aboriginal residents ensured that in the most literal sense, as a 'stranger', Andrew was not and could not be an 'owner of soil'. Though he expressed a love for the place, he was inserted into a geographic and ideological landscape in which the prevailing demographic majority and the normative behavioural dynamic were thoroughly Aboriginal.

Hence there is a genuine risk that an analytical focus on love might be seen to obfuscate enduring barriers in the genuine incorporation of 'strangers' into Aboriginal socialities. Indeed, as Venkatesan (in Venkatesan et al. 2011: 211) noted: 
the idiom of love might discursively underpin certain relations or, more strongly, might suffuse them, but the relations themselves play out in forms that can be studied without having to make 'love' the object of enquiry, or mobilise it as a form of explanation.

While Venkatesan's point is certainly true in the case of Andrew, it would be equally fair to say that the lack of emphasis on love as an analytic framework has resulted in a downplaying of the ties that bind and hence the application of a theory of love to interracial relationships is not solely aimed at romanticising relations that can be adequately theorised in other ways. It is striking that so many years after Myers (1979) called for attention to emotions (particularly focusing on Aboriginal informants, but applying in this case equally to non-Aboriginal persons) it remains the case that relatively scant attention has been given to the study of emotion in ways that he might have envisaged. Is it possible, we might ask, to develop frames for analysis of interracial relationships and the intersubjective nature of loving relationships which recognise the intimacies generated between those of different racial categories, while at the same time remaining attentive to those racial categories?

Here I have argued for an analytic frame for relationships between Aboriginal and non-Aboriginal people that seeks greater recognition of the attachments brought about by transformative personal experience. It is the body of these experiences which bring together and sustain relationships between those of (sometimes) vastly different socio-cultural backgrounds. This 'properly political' investigation, of a kind argued for by Berlant (2011) and Hardt (2011), is not then a narrative that suggests a naive incorporation of non-Aboriginal people, nor a romantic unification based on sameness. Rather, this approach pays attention to the localised instantiations of power: hierarchies which pervade intimacy but nonetheless are experienced by the individual. In doing so, I extend the frame for the inclusion of non-Aboriginal 'strangers', not only as part of a transactional idiom of kinship replete with expectation and obligations, but also as companions, lovers, life partners and soul mates that incorporates the full gamut of potential affective relations between individuals.

\section{ACKNOWLEDGEMENTS}

Thanks to 'Andrew' for sharing his experiences. Thanks to Nicolas Peterson and David Trigger for suggestions on drafts of the paper, and also to Richard J. Martin who was the co-convenor of the original conference session in 2011.

Please send correspondence to Cameo Dalley: cameo.dalley@anu.edu.au

\section{NOTES}

1 As a percentage of the total population, the number of non-Indigenous residents counted as living on Mornington Island has remained fairly stable between 2001 and 2011, from 103 nonAboriginal residents (12\% of the then total population) in 2001 (ABS 2001: Table B01) to 68 (7\%) in 2006 (ABS 2006: Table B07) and 120 (11\%) in 2011 (ABS 2011: Table B07). 
2 Some notable exceptions to this general characterisation include former missionaries, Shire Clerks and store keepers. Some of these people lived on Mornington Island for decades, raising their non-Aboriginal families there and maintaining connections by visiting for years afterward.

3 Here Aboriginal people were comparing the compound to the heavily fortified United States' military prison in Cuba used to house alleged terrorists.

4 Interestingly, however, at both the 2006 and 2011 Census all residents were born in Australia.

5 During my research two young White women moved (temporarily) to the island to live with their Aboriginal partners, though neither remained on the island long-term. Similar observances in the higher numbers of non-Aboriginal men partnered to Aboriginal women have been made by Musharbash (2010: 279) for Warlpiri Aboriginal people of Central Australia.

6 The same legislation applies to the former Presbyterian mission of Aurukun on western Cape York Peninsula in north Queensland.

7 It was very difficult to get a sense of whether or not these processes were formal or if the Whitefella's departure was enacted in other ways, such as rescinding their eligibility to local housing, therefore making it impossible for them to remain.

8 see Lardil Peoples v Queensland [2004] FCA 298 and Lardil, Yangkaal, Gangalidda \& Kaiadilt Peoples v State of Queensland [2008] FCA 1855.

9 The reality of this situation was more complex. All residents were able to access services and goods that were principally provided for the majority Aboriginal population. These included subsidised food at the local store and free medical care (including visiting specialists) and prescriptions at the local health service. In addition, Whitefellas employed by government (i.e. the majority living on the island) were generally in receipt of privileges which supported and encouraged them to remain working in the town. These included annual airfares to their 'hometown', higher pay rates than elsewhere and tax incentives for remote living. Despite the fact that all of these measures were paid for by the government, only those delivered on the island itself (i.e. housing, subsidised food and health services such as those accessed by Andrew) were thought to be part of 'the system'.

10 See also the work of Michèle Dominy for Pakeha (non-Maori) in the highlands of New Zealand's south island. One of Dominy's (1995: 367) informants, a Pakeha and former resident who had moved elsewhere, described her longing for the high country as 'a physical rather than a mental feeling. Some days I yearn for the mountains'.

\section{REFERENCES}

Austin-Broos, D. 2003 Places, practices, and things: the articulation of Arrernte kinship with welfare and work, American Ethnologist 30(1): 118-35.

Australian Bureau of Statistics [ABS] 2001 Table B01 'Selected Characteristics', Basic Community Profile (BCP) - Gununa (L) (Urban Centre/Locality). Canberra: Australian Bureau of Statistics. <http:// www.censusdata.abs.gov.au/census_services/getproduct/census/2001/communityprofile/UCL325300? opendocument\&navpos=220>, accessed 18 October 2011.

Australian Bureau of Statistics [ABS] 2006 Table B07 'Indigenous Status by Age by Sex', Table B08 'Ancestry by Country of Birth of Parents', Basic Community Profile (BCP) - Gununa (L) (Urban Centre/Locality). Canberra: Australian Bureau of Statistics. <http://www.censusdata.abs.gov.au/census_services/getproduct/ census/2006/communityprofile/UCL325300?opendocument\&navpos=220>, accessed 8 November 2007.

Australian Bureau of Statistics [ABS] 2011 Table B07 'Indigenous Status by Age by Sex', Table B08 'Ancestry by Country of Birth of Parents', Basic Community Profile (BCP) - Gununa (L) (Urban Centre/Locality). Canberra: Australian Bureau of Statistics. <http://www.censusdata.abs.gov.au/census_services/getproduct/ census/2011/communityprofile/UCL315039?opendocument\&navpos=220>, accessed 17 March 2013.

Berlant, L. 2011 A properly political concept of love: three approaches in ten pages, Cultural Anthropology 26(4): 683-91. 
Burbank, V. K. 1995 Passion as politics: romantic love in an Australian Aboriginal community, in (ed.) W. Jankowiak Romantic Passion: A Universal Experience? New York: Columbia University Press, pp 187-95.

Burbank, V. K. 2014 Envy and egalitarianism in Aboriginal Australia: an integrative approach, The Australian Journal of Anthropology 25(1): 1-21.

Carsten, J. 2011 Substance and relationality: blood in contexts, Annual Review of Anthropology 40: 19-35.

Cowlishaw, G. 2003 Euphemism, banality, propaganda: anthropology, public debate and Indigenous communities, Australian Aboriginal Studies 1: 2-18.

Cowlishaw, G. 2010 Helping anthropologists, still, in (eds) J. Altman and M. Hinkson Culture Crisis: Anthropology and Politics in Aboriginal Australia. Sydney: University of New South Wales Press, pp 4560.

Cowlishaw, G. 2012 Culture and the absurd: the means and meanings of Aboriginal identity in the time of cultural revivalism, Journal of the Royal Anthropological Institute 18: 397-417.

Dalley, C. 2012 Social relations and layered identities in a remote Aboriginal town, Mornington Island, Gulf of Carpentaria, Australia. PhD Thesis The University of Queensland.

Davis, R. 2004 Aboriginal managers as Blackfellas or Whitefellas? Aspects of Australian Aboriginal cattle ownership in the Kimberley, Anthropological Forum 14(1): 23-42.

Dominy, M. D. 1995 White settler assertions of native status, American Ethnologist 22(2): 358-74.

Gell, A. 1996 Amour, connaissance et dissimulation, Terrain 27: 5-14.

Glaskin, K. 2012 Anatomies of relatedness: considering personhood in Aboriginal Australia, American Anthropologist 114(2): 297-308.

Hamilton, A. 1972 Blacks and Whites: the relationships of change, Arena 30: 34-48.

Haraway, D. J. 1997 Modest_Witness@Second Millennium.FemaleMan@_Meets_OncoMouse ${ }^{T M}:$ Feminism and Technoscience. London: Routledge.

Hardt, M. 2011 For love or money, Cultural Anthropology 26(4): 676-82.

Herbert, X. 1938 Capricornia. Sydney: Angus and Robertson.

Herbert, X. 1975 Poor Fellow My Country. Sydney: Collins.

Herriman, N. 2012 Sorcery, theft and affinity: the estrangement of intimacy in Eastern Java, The Asia Pacific Journal of Anthropology 13(5): 454-68.

Huffer, V. with Elsie Roughsey and other women from Mornington Island. 1980 The Sweetness of the Fig: Aboriginal Women in Transition. Sydney: UNSW Press.

Jankowiak, W. and E. F. Fischer. 1992 A cross-cultural perspective on romantic love, Ethnology 31(2): 149-55.

Kowal, E. 2011 The stigma of White privilege, Cultural Studies 25(3): 313-33.

Kronqvist, C. 2012 Lost and found: selfhood and subjectivity in love, Philosophical Investigations 35: $205-23$.

Lea, T. 2012 Contemporary anthropologies of Indigenous Australia, Annual Review of Anthropology 41: $187-$ 202.

Mauss, M. 1954 [1950] The Gift: The Form and Reason for Exchange in Archaic Societies. W. D. Halls, trans. New York: Norton.

McGrath, A. 1987 'Born in the Cattle': Aborigines in Cattle Country. Sydney: Allen \& Unwin.

McGrath, A. 2005 Consent, marriage and colonialism: Indigenous Australian women and colonizer marriages, Journal of Colonialism and Colonial History 6(3): 1-23.

McKnight, D. 1999 People, Countries, and the Rainbow Serpent. Oxford: Oxford University Press.

McKnight, D. 2002 From Hunting to Drinking: The Devastating Effects of Alcohol on an Australian Aboriginal Community. London: Routledge.

McKnight, D. 2004 Going the Whiteman's Way: Kinship and Marriage Among Australian Aborigines. Aldershot: Ashgate.

McKnight, D. 2005 Of Marriage, Violence and Sorcery: The Quest for Power in Northern Queensland. Aldershot: Ashgate.

Merlan, F. 2005 Explorations towards intercultural accounts of socio-cultural reproduction and change, Oceania 75(3): 167-82.

Musharbash, Y. 2008 Yuendumu Everyday: Contemporary Life in Remote Aboriginal Australia. Canberra: Aboriginal Studies Press.

Musharbash, Y. 2010 Marriage, love magic, and adultery: Warlpiri relationships as seen by three generations of anthropologists, Oceania 80(3): 272-88.

Myers, F. 1979 Emotions and the self: a theory of personhood and political order among Pintupi Aborigines, Ethos 7(4): 343-70. 
Povinelli, E. 1995 What's love got to do with it? The race of freedom and the drag of descent, in (ed.) G. Baca Nationalism's Bloody Terrain: Racism, Class Inequality, and the Politics of Recognition. New York: Berghahn Books, pp 43-56.

Povinelli, E. 2002 Notes on gridlock: genealogy, intimacy, sexuality, Public Culture 14(1): 215-38.

Povinelli, E. 2006 The Empire of Love: Towards A Theory of Intimacy, Genealogy, and Carnality. London: Duke University Press.

Prichard, K. S. 1929 Coonardoo. London: Angus and Robertson.

Read, P. 2000 Belonging: Australians, Place and Aboriginal Ownership. Cambridge: Cambridge University Press.

Redmond, A. 2005 Strange relatives: mutualities and dependencies between Aborigines and pastoralists in the Northern Kimberley, Oceania 75(3): 234-46.

Robert, H. 2001 Disciplining the female Aboriginal body: inter-racial sex and the pretence of separation, Australian Feminist Studies 16(34): 69-81.

Shaw, B. 1992 When the Dust Come in Between: Aboriginal Viewpoints in the East Kimberley Prior to 1982. Canberra: Aboriginal Studies Press.

Simmel, G. 1950 The Sociology of Georg Simmel. K. H. Wolff, trans. New York: The Free Press.

Smith, B. R. 2003 Pastoralism, local knowledge and Australian Aboriginal development in northern Queensland, The Asia Pacific Journal of Anthropology 4(1): 88-104.

Smith, B. R. 2006 'More than love': locality and affects of indigeneity in Northern Queensland, The Asia Pacific Journal of Anthropology 7(3): 221-35.

Strathern, M. 1992 The decomposition of an event, Cultural Anthropology 7(2): 244-54.

Tonkinson, R. 1990 The changing status of Aboriginal women: 'free agents' at Jigalong, in (eds) R. Tonkinson and M. Howard Going it Alone? Prospects for Aboriginal Autonomy: Essays in Honour of Ronald and Catherine Berndt. Canberra: Aboriginal Studies Press, pp 125-47.

Tonkinson, M., R. Tonkinson. 2010 The cultural dynamics of adaptation in remote Aboriginal communities: policy, values and the state's unmet expectations, Athropologica 52(1): 67-75.

Townley, G. M. 2001 Missionaries, mercenaries and misfits: service relations in the administration of remote Aboriginal communities in the Western Desert Region of Australia. PhD Thesis University of Western Australia.

Trigger, D. 1989 Racial ideologies in Australia's Gulf country, Ethnic and Racial Studies 12(2): 209-32.

Trigger, D. 1997 Land rights and the reproduction of Aboriginal culture in Australia's Gulf Country, Social Analysis 41(3): 84-106.

Venkatesan, S., J. Edwards, R. Willerslev, E. Povinelli, P. Mody. 2011 The anthropological fixation with reciprocity leaves no room for love: 2009 meeting of the Group for Debates in Anthropological Theory, Critique of Anthropology 31(3): 210-50.

Vilaça, A. 2002 Making kin out of others in Amazonia, Royal Anthropological Institute 8: 347-65.

Viveiros de Castro, E. 2012 Immanence and fear: stranger-events and subjects in Amazonia, Journal of Ethnographic Theory 2(1): 27-43. 